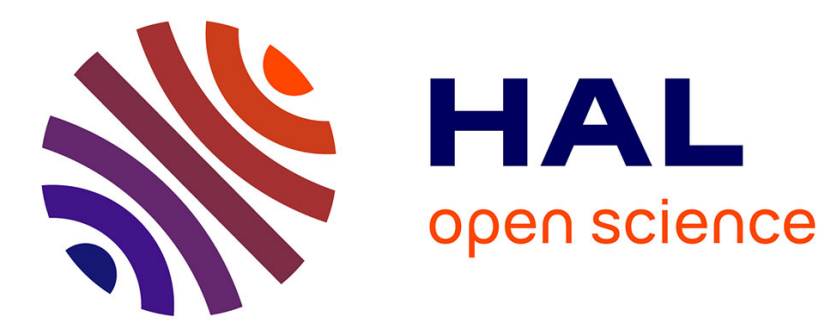

\title{
Quantitative sampling of freshwater shrimps: comparison of two electrofishing procedures in a Caribbean stream
}

\author{
E. Fievet, Luis Tito de Morais, A. Tito de Morais
}

\section{- To cite this version:}

E. Fievet, Luis Tito de Morais, A. Tito de Morais. Quantitative sampling of freshwater shrimps: comparison of two electrofishing procedures in a Caribbean stream. Archiv fur Hydrobiologie, 1996, 138 (2), pp.273-287. hal-01483104

\author{
HAL Id: hal-01483104 \\ https://hal.science/hal-01483104
}

Submitted on 3 May 2020

HAL is a multi-disciplinary open access archive for the deposit and dissemination of scientific research documents, whether they are published or not. The documents may come from teaching and research institutions in France or abroad, or from public or private research centers.
L'archive ouverte pluridisciplinaire HAL, est destinée au dépôt et à la diffusion de documents scientifiques de niveau recherche, publiés ou non, émanant des établissements d'enseignement et de recherche français ou étrangers, des laboratoires publics ou privés. 


\title{
Quantitative Sampling of freshwater shrimps: comparison of two electrofishing procedures in a Caribbean stream
}

\author{
Eric Fièvet ${ }^{1}$, Luis Tito de Morais ${ }^{2}$ and Anne Tito de Morais ${ }^{2}$ \\ 1 - ESA CNRS n 5023 “Ecologie des Eaux Douces et des Grands Fleuves”, Univ. Lyon I, F- \\ 69622 Villeurbanne Cedex, France. \\ 2 - Centre ORSTOM, BP 1434, Bouaké, 01, Ivory Coast.
}

\begin{abstract}
Two electrofishing procedures (point abundance sampling and removal sampling) for estimating community structure and the abundance of freshwater shrimps (Decapoda: Natantia) were compared at five sites in the Grand-Carbet River, Guadeloupe, French West Indies, on the basis of species richness, species frequency and the length of caught individuals. Sampling was carried out using battery-powered portable electric fishing gear. Both point abundance sampling and removal procedures highlighted a steep longitudinal gradient related to the shrimp fauna and no consistent discrepancy was observed between the two procedures in the different sites. Thus, the choice of one of these two procedures will depend only on the study objective. The benefits and disadvantages of these íwo electrofishing procedures are concisely discussed.
\end{abstract}

\section{Introduction}

Electrofishing is widely used as a sampling technique for fish in temperate and tropical streams due to its ability to collect large samples (BOHLIN et al. 1989, PENCZAK \& LASSO 1991, BARAS $1995)$ even though the species and size selectivity of electrofishing has been demonstrated in the field (REYNOLDS 1983, KLEIN BRETELER et al. 1990, LAMARQUE 1990). Electrofishing is also efficient for freshwater shrimps (GILLET 1983, PENCZAK \& RODRIGUEZ 1990, TITO DE MORAIS et al. 1993) which often occupy neotropical mountain Streams in high densities (CHACE \& HOBBS 1969, GILLET 1983, COVICH 1988). In isolated insular streams, freshwater shrimps play an important role by filling gaps in the food web left by certain missing or poorly represented mainland taxa (e.g., larvae of predatory stoneflies (BAUMANN 1982), larvae of predatory and filter-feeding caddisflies and black flies (COVICH 1988)). Most studies investi- gating freshwater shrimps have used hand-nets (WALKER \& FERREIRA 1985) or traps with bait (VALENTI et al. 1986, COVICH et al. 1991, ODINETZ-COLLART \& MAGALHAES 1994). Hand-nets are a fairly qualitative method and netting (lato sensu) is difficult to set up in lotic systems with high velocity (PENCZAK \& RODRIGUEZ 1990, TITO DE MORAIS et al. 1993). Trapping is a largely biased method in community studies as it depends on animal behaviour (e.g., territo- riality), diet (via foraging aptitude and the bait used), and individual length (e.g., in FOUILLAND \& FOSSATI, in press). Direct underwater observations (e.g., snorkelling, camera use) are inappropriate in shallow riffles (HELFMAN 1983). Lastly, poisoning is perceived as too destructive a technique (TITO DE MORAIS et al. 1993). Thus, electrofishing has been used in studies on the structure of shrimp communities along different fast-flowing neotropical streams. Among electrofishing procedures, PENCZAK \& RODRIGUEZ (1990) used the depletion method in Venezuela and TITO DE MORAIS et al. (1993) used the removal method in Guadeloupe.

JACKSON \& SWEENEY (1995) recently underlined that much is still to be learnt about tropical streams and that "similarities and differences among the various types of tropical streams need to be understood before accurate generalisations about the streams can be conceptualised". To reach JACKSON \& SWEENEY'S objective, the development of sampling procedures that consider field conditions and provide reliable quantitative data at reduced costs must be given priority. These procedures must be tested too. In the present study, we have compared point abundance sampling 
(NELVA et al. 1979, PERSAT \& COPP 1990, GARNER 1995) with removal sampling (SHELDON 1968, BOHLIN et al. 1989). Comparisons were based on three fundamental parameters of community structure: species richness, species frequency and size frequency distribution. The aim was to check any possible bias between the two procedures at 1) small-scale (stream segment) and 2) large-scale (watershed). The stream studied was the Grand-Carbet River, a relatively well-documented stream in the Guadelupian Archipelago. Because certain sampling sites were in the Guadeloupe National Park, sampling could not be destructive and most captured shrimps were released.

\section{Material and methods}

\section{Study area and sampling sites}

The Guadelupian Archipelago is part of the Lesser Antilles. It consists of two main islands separated by a narrow salty channel. The first island, Grande-Terre, is a low limestone plateau, and the second, Basse-Terre, is composed of a North-South volcanic range ( Fig. 1 a). The Basse-Terre piedmont is close to the sea-shore and the coastal plain is very narrow. In this topographical setting, annual rainfall is drained via numerous fast-flowing streams. Five study sites in one of these streams, the Grand-Carbet River, were chosen in order to compare point abundance sampling and removal sampling (Fig. 1 b). Grand-Carbet River is fast flowing along nearly all its course and can be considered, according to preliminary reports (LEVEQUE 1974, STARMUHLNER \& THEREZIEN 1982, GILLET 1983, TITO DE MORAIS et al. 1993), as a "permanent stream in which the [decapod faunal] gradient is steep from source almost to mouth, usually with clear water, and without estuarine or subestuarine development" (definition by CHACE \& HOBBS (1969), p. 43). The five study sites were located at 15, 100, 200, 436 and 540 metres a.s.1. They corresponded to sites already studied by one, of us in 1991 and 1992 before the damming of the river at the 210-metres mark a.s.1. (TITO DE MORAIS et al. 1993). The two higher sites were in the Guadeloupe National Park. Some physical and chemical characteristics of the sites during the field work are listed in Table 1. Annual rainfall of $6061 \pm 640 \mathrm{~mm}$ (mean \pm SD over 1961-1990 period) occurs at 720m elevation (BLEUSE \& MANDAR 1993). Data were collected in the late dry period (March 1995) when the stream flow was lowest and the water was clear. Shrimp sampling was carried out during the day (10:00-17:00).

\section{Sampling procedures}

This study involved two different quantitative procedures: removal sampling (RS) and point abundance sampling (PAS). Quantitative shrimp collections were all made using battery-powered portable electric fishing gear ('Martin Pêcheur II', see Appendix 1).

For RS, block nets (10-mm stretched mesh) were placed at natural weirs in the channel at both up- and downstream ends of sample sites (reach delimitation), then repeated electrofishings were used to make samples as exhaustive as possible. Electrofishing was stopped when the number of newly caught individuals decreased to less than one per fishing minute. Two runs by 3 or 4 persons progressing downstream through each reach were sufficient. The first run lasted generally 2.0-2.5 hours and the second about 1.0 hour.

PAS consisted in collecting a great number of small-sized samples evenly distri- buted over the site investigated without limiting the sites with nets. Each point sample was limited to the attraction area around the anode. Successive point samples were collected about $10 \mathrm{~m}$ apart to minimise fright bias (GARNER 1995). At each point, the fishing electrode was submerged twice ( $2 \times 15$ seconds) and one minute elapsed between these two actions. Shrimps that did not leave their hiding place at first sometimes moved during the second action, and could thus be caught. 
Shrimps were collected using fine dip nets with PAS and in the downstream block net and dip nets in RS.

\section{Material collected}

A total of 5,867 shrimps longer than $5 \mathrm{~mm}$ in total length (TL) were collected. They were generally identified to species level using CARVACHO \& CARVACHO'S keys (1976) and all measured to the nearest millimetre (TL), then released. TL was determined from the tip of the rostrum to the tip of the telson. Small shrimps were preserved in ethyl alcohol and later identified and measured in the laboratory.

Among the thirteen freshwater shrimp species known from Guadeloupe (LEVEQUE 1974), we collected ten species. They belonged to atyids: Atya innocous (HERBST), Atya scabra (LEACH), Jonga serrei (BOUVIER), Micratya poeyi (GUERIN-MENEVILLE) and Xiphocaris elongata (GUERN-MENEVILLE), and palaemonids: Macrobrachium carcinus (LINNAEUS), Macrobrachium heterochirus (WIEGMANN), Macrobrachium faustinum (DE SAUSSURE) and Macrobrachium crenulatum (HOLTHUIS). Captured specimens of Potimirim (two species in Guadeloupe) were not identified to species level. The non-captured species: Macrobrachium acanthurus (WIEGMANN) and Palaemon pandaliformis (STIMPSON) characteristically frequent the mouths of quiet streams (CHACE \& HOBBS 1969) and were not yet reported by TITO DE MORAIS et al. (1993) from the Grand-Carbet River.

Associated fauna captured by means of electrofishing consisted of fishes: Chonophorus sp., Agonostomus monticola, Anguilla rostrata and Eleotris pisonis, and was dominated by Gobies (Sicydium spp.).

\section{Statistical analyses}

Differences between species richness (total number of species observed in each site) and the relative frequencies of species obtained from the different procedures were tested using contingency table analyses. The effect of site and procedure on the mean length of the main species (A. innocous, $M$. faustinum and $M$. poeyi) were tested at a large scale using a two-way analysis of variance. Homogeneity of variances was achieved by taking the natural logarithm of TL. Small-scale differences in mean length were tested for each site by Kruskall-Wallis U-tests for small samples and Student ttests for the others (SPRENT 1989). Q-Q plots (curves of centiles comparison) enabled the local differences to be specified due to a systematic deviation curve-bisector (or some parts of the curvebisector) that indicates a bias and to a great distance curve-bisector that denotes inaccuracy. Statistical analyses were carried out using Statview ${ }^{\mathrm{TM}}$ software.

\section{Results}

Despite strong variations of density between sites: from 1.37 to $10.45 \mathrm{ind} . / \mathrm{m}^{2}$ or 9.65 to 41.05 ind./point abundance sample, we caught large total numbers of freshwater shrimps in all sites (Tables 2 and 3).

\section{Species richness comparison}

Using 96 point abundance samples we caught 1,726 shrimps and in 5 RS reaches $\left(870 \mathrm{~m}^{2}\right) 4,141$ individuals. In spite of a lower total number of shrimps caught, PAS allowed 10 shrimp species to be caught of which two (Potimirim sp. and $J$. serrei) were not found using RS (Tables 2 and 3 ).

Nevertheless, the number of species caught in each site was not consistently higher with PAS, in some sites it was higher with RS (Fig. 2), and no systematic bias was observed between these two procedures ( $p>0.05, \chi^{2}$ test). The difference in numbers of species captured between the two procedures 
shows that certain species such as serrei are scarce in the sampling sites (Tables 2 and 3). Overall, species richness decreased in relation to altitude whatever procedure we used (Fig. 2). Three species dominated the Grand-Carbet shrimp fauna, two atyid shrimps (A. innocous and $M$. poeyi) and one palaemonid shrimp (M. faustinum). Seven other shrimp species occurred at low frequencies: $A$. scabra, Potimirim sp., J. serrei, X. elongata, M. heterochirus, $M$. carcinus and $M$. crenulatum. The seven latter species constitute the "other" category in Fig. 3. M. faustinum and M. poeyi formed the major components of the shrimp fauna in the lower sites, $M$. poeyi in site 3 , and A. innocous dominated in the higher sites (Fig. 3).

Values for species frequency varied strongly between the different proce- dures $(\mathrm{p}<0.001$, test), in particular in site 2 where $M$. poeyi more clearly dominated the shrimp community according to the RS procedure (Fig. 3 ).

\section{Individual length comparison}

The mean length of $A$. innocous, $M$. faustinum and $M$. poeyi was calculated for each sampling procedure at the different sampling sites (Fig. 4). For each of these species, mean length was greater in the upstream sites ( $<<0.001$, ANOVA tests, Fig. 4).

Sampling procedures showed significant differences for the values of mean TL at sites 4 and 5 for $A$. innocous ( $<<0.001$, t-tests) and at site 2 for $M$. faustinum $(\mathrm{p}=0.018$, $\mathrm{t}$-test $)$ and $M$. poeyi $(\mathrm{p}<0.001, \mathrm{t}$-test). For these four significant occurrences, the comparison curve of centiles remains either below or above the first bisecting line (Fig. 5). Thus, a bias appeared in some sites but cannot be generalised. However, due to the lack of large individuals of $M$. faustinum and M. poeyi at site 3 using PAS, larger individuals were caught overall by RS on five occasions, smaller on only one occasion and individuals of the same length were caught on five occasions (Fig. 5).

Despite length differences at some sites, PAS and RS showed similar longitudinal gradients of shrimp size that increased with distance from the river mouth.

The longitudinal shrimp distribution and abundance in relation to physical habitat will be more precisely investigated throughout the island in another paper.

\section{Discussion}

As it provides large samples, electrofishing is a well-adapted sampling technique for studying freshwater shrimp communities (e.g., PENCZAK \& RODRIGUEZ 1990, TITO DE MORAIS et al. 1993). PENCZAK \& RODRIGUEZ (1990) achieved a catch efficiency higher than 0.5 for shrimps in the Todasana River, a Grand-Carbet River equivalent in Venezuela. The same rough estimate was encountered for fishes from the same study area (PENCZAK \& LASSO 1991).

PENCZAK \& RODRIGUEZ (1990) found a lower catch efficiency in riffle areas than in pools because of the difficulty in seeing and dip-netting small individuals. The catchability of bottomdwelling organisms is strongly depend- ent on the facility of locating stunned animals. High velocities will more easily sweep small shrimps than larger ones hidden among the boulders during daylight hours (e.g., Macrobrachium spp., personal observations). As a consequence, catch efficiency depends on velocity and individual size. A steep longitudinal gradient characterised the biotic and abiotic factors in the Grand-Carbet River, particularly velocity (Table 1) and shrimp size (Fig. 4) that both increased with elevation. The catch efficiency consequently differed between sites. However, as sampling conditions were the same within sites, we could directly compare the results of the two electrofishing procedures investigated in this study. 
The benefits and disadvantages of point abundance sampling (PAS) and removal sampling (RS) procedures are given in Table 5. Both procedures led to similar faunistic gradients at a large scale (watershed). However, they sometimes yielded significantly different evaluations (e.g., individual mean length, species frequencies) at the small scale (stream segment) despite no perceptible systematic bias between the two procedures. According to the spatial scale considered and the sampling aims, these differences must be taken into account.

Substrate heterogeneity and large rocks (diam. $>1 \mathrm{~m}$ ) prevent the use of improved electrofishing techniques on small fishes in temperate streams using prepositioned frame electrodes (BARAS 1995, BAIN et al. 1985). Moreover, the difficult access of mountain sites (sometimes requiring several hours of walk- ing) makes the equipment developed by these authors impractical.

In terms of sampling representativeness, PAS accounted for the highest number of species in this study because this procedure allowed the sampling of a greater number of (micro-) habitats than the RS procedure. If the aim of a study is a taxonomic survey of the shrimp community PAS would be recommendable. Moreover, the number of sampling points can be increased to improve sample representativeness and to consider a greater variety of habitats.

PAS is less time-consuming than RS that requires reach delimitation and more manpower. For instance, two fishermen during a period of 1.5-2.5 hours could carry out 20 PAS while three or four fishermen were required for almost 3 hours to capture shrimps in a $150 \mathrm{~m}^{2}$ stream reach in the present work.

Generally, ecological studies require not only enumeration of the species habitats (e.g., substrate type, deep pool, shade) but also quantification of the relative availability of the habitats considered. This is also true for resource (e.g., algal cover) quantification. With PAS, resource or microhabitat enumeration can be related to the spatial distribution of species (e.g., in GARNER 1995). Thus, PAS is well-adapted for studying microhabitat-species relationships. In contrast, RS pools the microhabitat characteristics of each site and so permits only comparisons between stream reaches.

By means of a great number of sampling points taken in the field, PAS permits the study of scarce species such as $M$. carcinus in this study. An autecological perspective may be developed with this procedure not only for abundant species but for scarce species also. In contrast, RS permits autecological studies of only abundant species such as $A$. innocous in certain sites (Table 3 ). Consequently, according to the sampling aims and target species, PAS or RS should be preferred.

RS is better adapted for estimating living stock (density in a given area), but extrapolations remain imprecise because the replications are a waste of time and, in large reaches, it is difficult to catch all the shrimps present, which leads to underestimated densities. PAS avoids the crucial problem of the lack of replications within sites but the determination of absolute density or biomass is difficult because the efficient range around the anode varies in relation to many variables (e.g., species size, velocity, voltage selected, etc.). The method described by REGIS et al. (1981) for evaluating in situ the efficient range around the anode in relation to such variables may be applied to the evaluation of densities by PAS but requires additional labour.

Finally, because the present work highlighted no consistent discrepancy between PAS and RS, samples carried out by the two procedures can be compared in the same way as samples carried out by one procedure. However, if density is not relevant, PAS provides flexible quantitative data at lower costs than RS. Moreover, PAS can be used at small and/or larger scales; from micro-distribution (microhabitat use) to longitudinal gradient (watershed) or for comparisons between the faunas from different stream types. Thus, PAS should be increasingly used in Caribbean streams and elsewhere, to quickly collect reliable data on freshwater-shrimp (and fish) community structure and their ecology. 


\section{Acknowledgements}

We particularly thank Dr. H. TACHET (Univ. Lyon I) and Dr. L. REDAUD (Guadeloupe National Park) for advice during the course of this research, and L. GARCIN and persons serving Voluntary Service Overseas for assistance in the collection of shrimps. We thank Drs N. G. YOCCOZ, S. DOLEDEC, H. PERSAT (Univ. Lyon I) and two anonymous referees for critical comments on the ideas and work presented. L. HILL and K. SIMON provided linguistic assistance with the English text and $\mathrm{J}$. TACHET drew the figures.

The present work was supported by Administrative Agreement $\mathrm{N}^{\circ}$ 95-01 between the Freshwater and River Ecology Research Unit (ESA CNRS N 5023, Univ. Lyon I) and the Guadeloupe National Park, and was conducted using the substructure and equipment of this park.

\section{References}

- BAIN, M. B., FINN, J . T. \& BOOKE, H. E. (1985): A quantitative method for sampling riverine microhabitats by electrofishing. - North Amer. Fish. Manage. 5: 489- 493.

- BARAS, E. (1995): An improved electrofishing methodology for the assessment of habitat use by young-of-the-year fishes. -Arch. Hydrobiol. 134: 403-415.

- BAUMANN, R. W. (1982): Plecoptera. - In: HURLBERT, S. H. \& VILLALOBOS-FIGUEROA, A. (eds.): Aquatic biota of Mexico, Central America and the West Indies. San Diego State University, pp. 278-279.

- BLEUSE, N. \& MANDAR, C. (1993): Le régime pluviométrique de la Guadeloupe. - La Météorologie 8: 42-56.

- BOHLIN, T., HAMRIN, S., HEGGBERGET, T. G., RASMUSSEN, G. \& SALTVEIT, S. V. (1989): Electrofishing - Theory and practice with special emphasis on salmonids. Hydrobiologia 173: 9-43.

- CARVACHO, A. \& CARVACHO, C. (1976): Une clé illustrée pour la détermination des crevettes d'eau douce de la Guadeloupe. - Nouv. Agron. Antilles-Guyane 2: 211- 219.

- CHACE, F. A. \& HOBBS, H. H. (1969): The freshwater and terrestrial decapod crusta- ceans of the West Indies with special reference to Dominica. - U.S. Nat. Mus. Bull. 292: 1-258.

- COVICH, A. P. (1988): Atyid shrimp in the headwaters of the Luquillo Mountains, Puerto Rico: filter feeding in natural and artificial streams. - Verh. Int. Verein. Limnol. 23: 2108-2113.

- COVICH, A. P., CROWL, T. A., JOHNSON, S. L., VARZA, D. \& CERTAIN, D. L. (1991): Post-hurricane Hugo increases in atyid shrimp abundances in a Puerto Rican montane stream. Biotropica 23: 448-454.

- FOUILLAND, E. \& FOSSATI, O. (in press): Trapping efficiency of plastic bottle 'wickertraps' for population assessment of river Macrobrclchinrn (Crustacea, Decapoda). - Fish. Res.

- GARNER, P. (1995): Suitability indices for juvenile O+ roach [Rutilus rutilus (L.)] using point abundance sampling data. - Regul. Riv. 10: 99-104.

- GILLET, C. (1983): Les peuplements de poissons et de crevettes des rivières de la Guadeloupe: quelques données sur la biologie, la reproduction et la répartition des espèces. -Rev. Hydrobiol. trop. 16: 327-340.

- HELFMAN, G. S. (1983): Underwater methods. - In: NIELSEN, L. A. \& JOHNSON, D. L. (eds.): Fisheries Techniques. - American Fisheries Society Bethesda, Maryland, pp. 349-369.

- JACKSON, J. K. \& SWEENEY, B. W. (1995): Present status and future directions of tropical stream research. - J . N. Amer. Benthol. Soc. 14: 5-11.

- KLEIN BRETELER, J. G. P., RAAT, A. J. P. \& GRIMM, M. P. (1990): Efficiency and selectivity in fishing with electricity. - In: Cowx, I. G. (ed.): Developments in Electric Fishing. Fishing News Books. Blackwell Scientific Publications, Oxford, pp. 219-228. 
- LAMARQUE, P. (1990): Twenty years of electric fishing expeditions throughout the world. In: Cowx, I. G. (ed.): Developments in electric fishing. - Fishing News Books. Blackwell Scientific Publications, Oxford, pp. 344-351.

- LEVEQUE, C. (1974): Crevettes d'eau douce de la Guadeloupe (Atyidae et Palaemonidae). Cah. ORSTOM, série Hydrobiol. 13: 41-49.

- NELVA, A., PERSAT, H. \& CHESSEL, D. (1979): Une nouvelle méthode d'étude des peuplements ichtyologiques dans les grands cours d'eau par échantillonnage ponctuel d'abondance. - C. R. Acad. Sci., Paris 289 (D): 1295-1298.

- ODINETZ-COLLART, O. \& MAGALHAES, C. (1994): Ecological constraints and life history strategies of palaemonid prawns in Amazonia. -Verh. Int. Verein. Limnol. 25: 2460-2467.

- PENCZAK, T. \& LASSO, C. (1991): Problems of estimating population parameters and production of fish in a tropical rain forest stream, North Venezuela. - Hydrobiologia 215: 121133.

- PENCZAK, T. \& RODRIGUEZ, G. (1990): The use of electrofishing to estimate population densities of freshwater shrimps (Decapoda, Natantia) in a small tropical river, Venezuela. -Arch. Hydrobiol. 118: 501-509.

- PERSAT, H. \& COPP, G. H. (1990): Electric fishing and point abundance sampling for the ichthyology of large rivers. - In: Cowx, I. G. (ed.): Developments in electric fishing. - Fishing News Books. Blackwell Scientific Publications, Oxford, pp. 197-209.

- REGIS, J., PATTEE, E. \& LEBRETON, J. D. (1981): A new method for evaluating the efficiency of electric fishing. -Arch. Hydrobiol. 93: 68-82.

- REYNOLDS, J. B. (1983): Electrofishing. - In: NIELSEN, L. A. \& JOHNSON, D. L. (eds.): Fisheries Techniques. - American Fisheries Society Bethesda, Maryland, pp. 147- 163.

- SHELDON, A. L. (1968): Species diversity and longitudinal succession in stream fishes. Ecology 49: 193-198.

- SPRENT, P. (1989): Applied nonparametric statistical methods. - Chapman \& Hall, London.

- STARMUHLNER, F. \& THEREZIEN, Y. (1982): Résultats de la mission hydrobiologique austro française de 1979 aux îles de la Guadeloupe, de la Dominique et de la Martinique (Petites Antilles). I - Etude générale de la Guadeloupe. - Rev. Hydrobiol. trop. 15: 131-150.

- TITO DE MORAIS, L., MONTI, D., RAMBAUD, V. \& LAUZANNE, L. (1993): Etude hydrobiologique de la rivière du Grand Carbet, Basse-Tesre, Guadeloupe. - Rapport final. Convention ORSTOM-SUMATEL-PNG, centre ORSTOM, Pointe-à-Pitre, France.

- VALENTI, W. C., CARDOSO DE MELLO, J. T. \& LOBAO, V. L. (1986): Dinâmica da reprodução de Macrobrachium acanthurus (WIEGMANN, 1836) e Macrobrachium carcinus (LINNAEUS, 1758) do Rio Ribeira de Iguape (Crustacea, Decapoda, Palaemonidae). - Ciência e Cultura, São Paulo 38: 1256-1262.

- WALKER, I. \& FERREIA, M. J . N. (1985): On the population dynamics and ecology of shrimp species (Crustacea, Decapoda, Natantia) in Central Amazonian river Tarumã-Mirim. Oecologia 66: 264-270.

\section{Appendix 1}

Characteristics of the backpack fishing device used. Commercial name: 'Martin Pêcheur II'. Firm: DREAM ELECTRONIQUE F33750, Saint-Germain-du-Puch, France. Power source: cadmium-nickel battery $12 \mathrm{~V}, 10 \mathrm{~A}$. Currents produced: rectangular pulsed DC: 100 or $400 \mathrm{~Hz}$, duty cycle: from 10 to $50 \%$, peak voltage: 150,200 or $300 \mathrm{~V}$, power max.: about $100 \mathrm{~W}$. Current usually used in GrandCarbet River: $400 \mathrm{~Hz}$ - 300V 40 \% - P max. Anode diam.: $30 \mathrm{~cm}$. 
Figures and tables

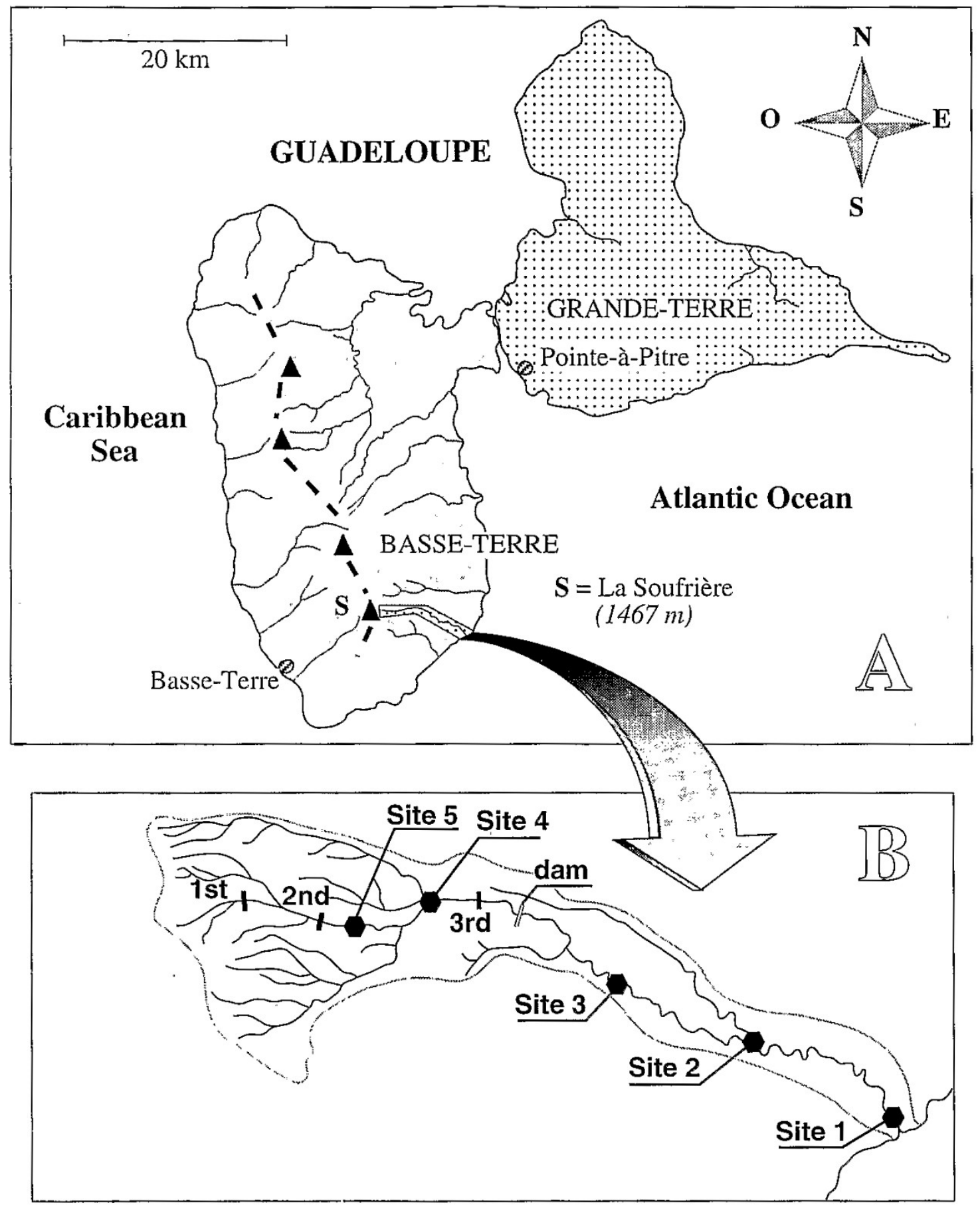

Fig. 1. Study area: the two parts (Basse-Terre and Grande-Terre) of the Guadeloupe Island with the main cities and streams. (A): the Grand-Carbet River watershed with sampling sites; (B): 1st = First Waterfall $($ declivity $=115 \mathrm{~m}), 2 \mathrm{nd}=$ Second Waterfall $(\mathrm{d}=110 \mathrm{~m})$ and $3 \mathrm{rd}=$ Third Waterfall $(\mathrm{d}=20 \mathrm{~m})$. 


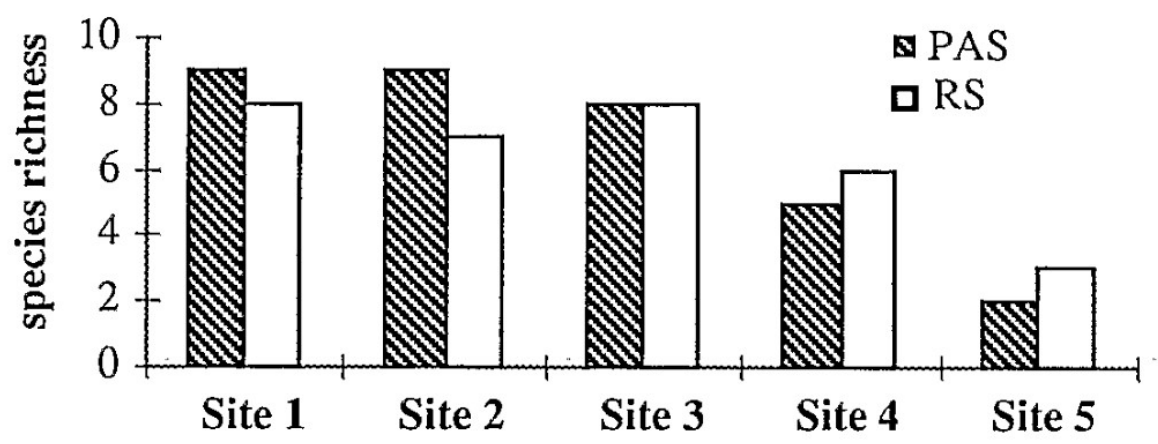

Fig. 2. Species richness in the sampling sites according to PAS and RS. Shrimp numbers used for calculations are indicated in Tables 2 and 3. 


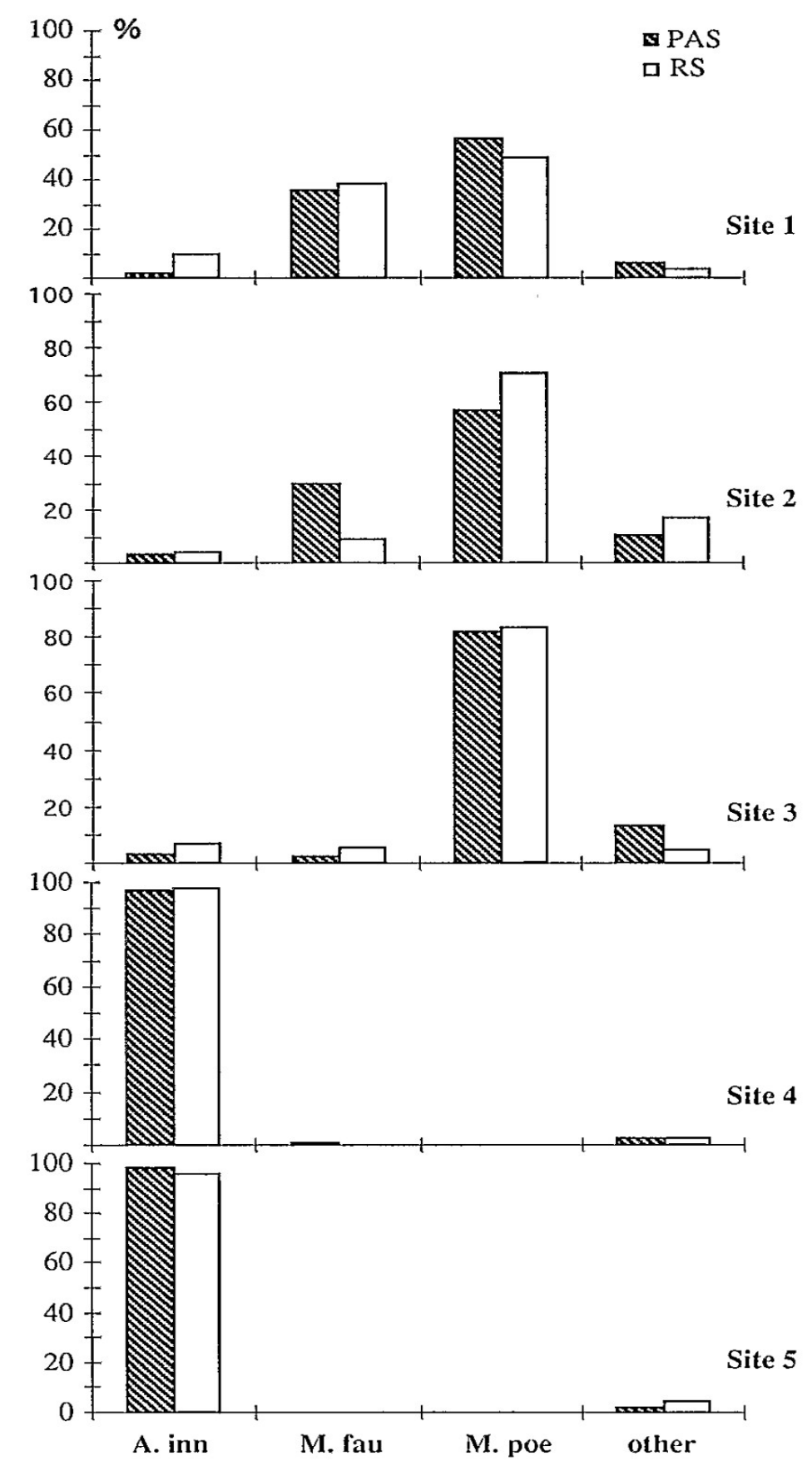

Fig. 3. Community structure in percent between the different sampling sites according to PAS and RS. Shrimp numbers used for calculations are indicated in Tables 2 and 3. See text for species list of the "other" category. A. inn = Atya innocous, M. fau = Macrobrachium faustinum, M. poe = Micratya poeyi. 


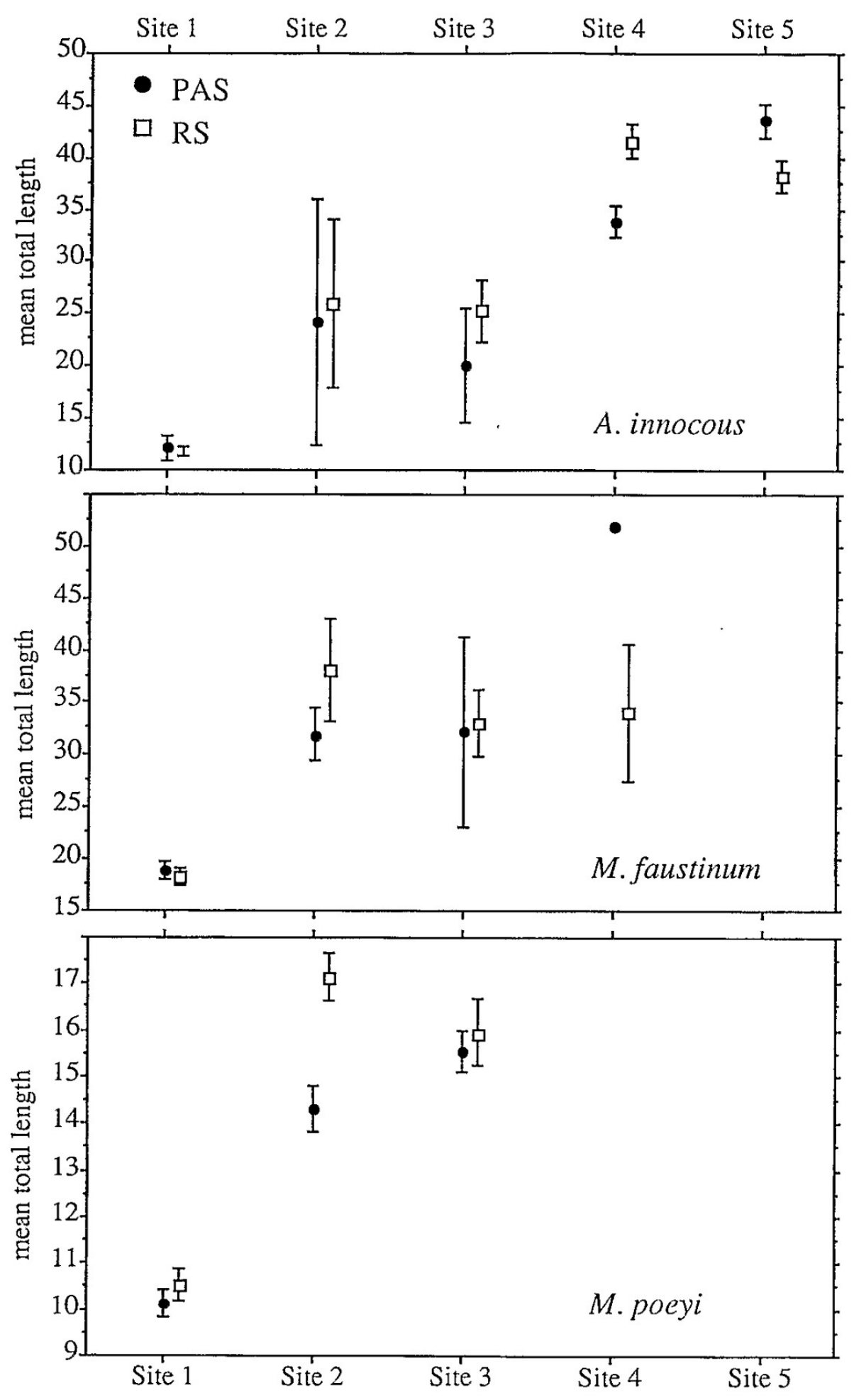

Fig. 4. Mean total length ( $\pm 95 \%$ CI) of Atya innocous, Macrobrachium faustinum and Micratya poeyi according to PAS and RS in the different sampling sites. Note that scales are not the same on all graphs. 
A. innocous
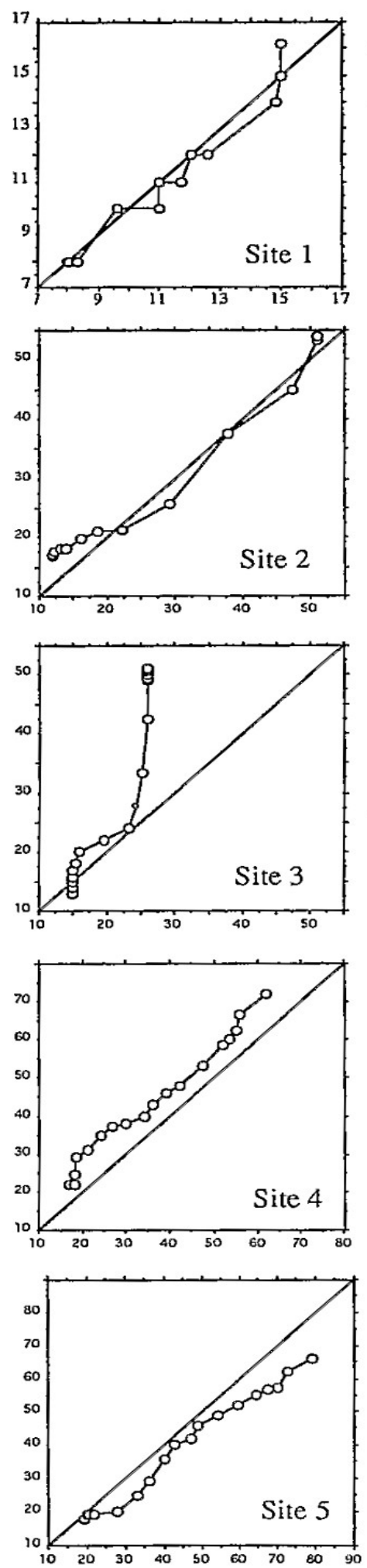

M. faustinum
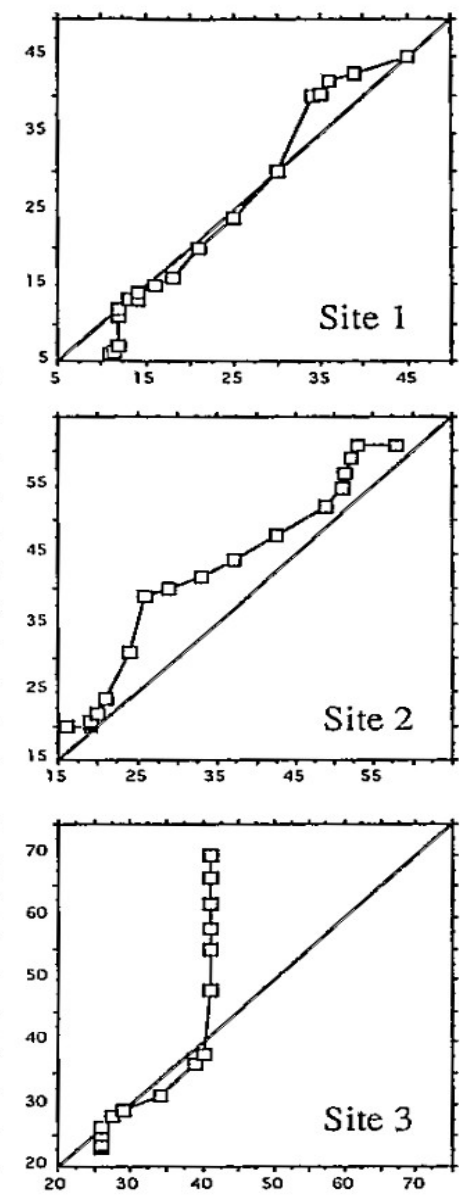

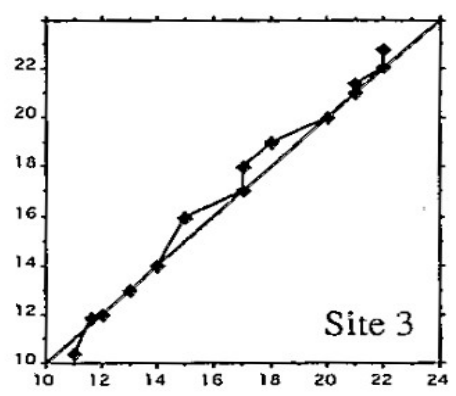

M. poeyi
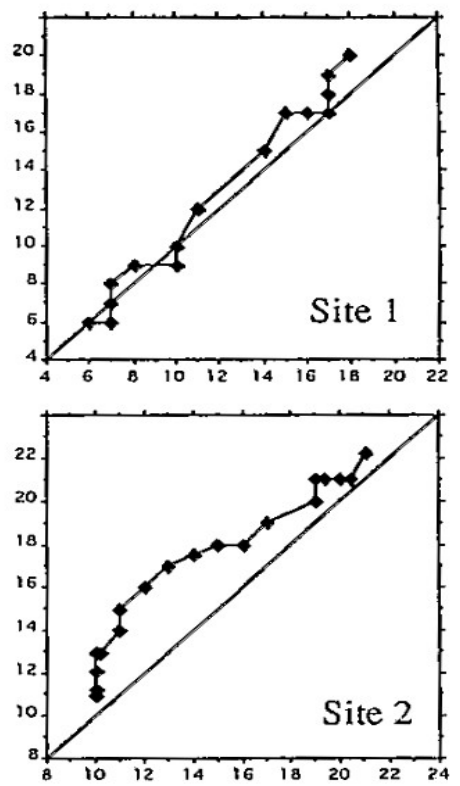

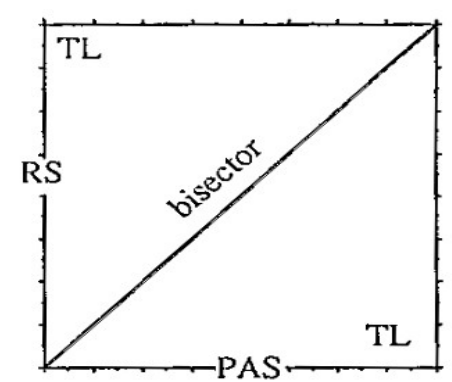

Fig. 5. Q-Q plots (PAS vs. RS) of Atya innocous, Macrobrachium faustinum and Micratya poeyi in the different sampling sites. Note that scales are not the same on all graphs. 
Table 1. Characteristics of sampling sites.

\begin{tabular}{llllll}
\hline & Site 1 & Site 2 & Site 3 & Site 4 & Site 5 \\
\hline altitude $(\mathrm{m})$ & 15 & 100 & 200 & 436 & 540 \\
catchment area $\left(\mathrm{km}^{2}\right)$ & 11.8 & 9.8 & 9.6 & 4.9 & 1.9 \\
sea distance $(\mathrm{km})$ & 0.4 & 2.3 & 4.0 & 6.6 & 7.4 \\
slope $(\%)$ & 3.8 & 4.4 & 5.1 & 6.7 & 7.3 \\
width $(\mathrm{m})$ & 25 & 25 & 20 & 15 & 10 \\
velocity $(\mathrm{cm} / \mathrm{s})$ & $25-50$ & $25-50$ & $50-75$ & $50-75$ & $50-75$ \\
temperature $\left({ }^{\circ} \mathrm{C}\right)$ & 26.0 & 23.5 & 23.5 & 21.0 & 22.0 \\
$\mathrm{pH}$ & 7.1 & 7.1 & 7.2 & 7.3 & 7.1 \\
conductivity $(\mu \mathrm{S} / \mathrm{cm})$ & 310 & 316 & 312 & 180 & 199 \\
\hline
\end{tabular}

Table 2. Shrimp numbers captured at the different sampling sites by means of PAS, with the numbers of sampling points.

\begin{tabular}{lrrrrr}
\hline & Site 1 & Site 2 & Site 3 & Site 4 & Site 5 \\
PAS numbers & 20 & 20 & 20 & 16 & 20 \\
\hline A. innocous & $\mathbf{1 5}$ & $\mathbf{8}$ & $\mathbf{6}$ & $\mathbf{1 8 1}$ & $\mathbf{2 4 9}$ \\
M. faustinum & $\mathbf{2 9 2}$ & $\mathbf{7 9}$ & $\mathbf{5}$ & $\mathbf{1}$ & $\mathbf{0}$ \\
M. poeyi & $\mathbf{4 6 3}$ & $\mathbf{1 5 4}$ & $\mathbf{1 5 7}$ & $\mathbf{0}$ & $\mathbf{0}$ \\
A. scabra & 0 & 1 & 4 & 0 & 0 \\
J. serrei & 1 & 0 & 0 & 0 & 0 \\
M. carcinus & 1 & 1 & 1 & 0 & 0 \\
M. crenulatum & 2 & 6 & 9 & 0 & 0 \\
M. heterochirus & 9 & 16 & 4 & 3 & 5 \\
Potimirum sp. & 1 & 2 & 0 & 1 & 0 \\
X.elongata & 37 & 3 & 7 & 2 & 0 \\
total & 821 & 270 & 193 & 188 & 254 \\
number by point & 41.05 & 13.50 & 9.65 & 11.75 & 12.70 \\
\hline
\end{tabular}

Table 3. Shrimp numbers captured at the different sampling sites by means of RS, with the sampling surface.

\begin{tabular}{lrrrrr}
\hline & Site 1 & Site 2 & Site 3 & Site 4 & Site 5 \\
sampling surface $\left(\mathrm{m}^{2}\right)$ & 240 & 200 & 170 & 110 & 150 \\
\hline A. innocous & $\mathbf{1 6 7}$ & $\mathbf{1 1}$ & $\mathbf{5 1}$ & $\mathbf{1 1 1 7}$ & $\mathbf{2 4 6}$ \\
M. faustinum & $\mathbf{6 4 2}$ & $\mathbf{2 4}$ & $\mathbf{4 3}$ & $\mathbf{3}$ & $\mathbf{0}$ \\
M. poeyi & $\mathbf{8 1 0}$ & $\mathbf{1 9 2}$ & $\mathbf{6 5 5}$ & $\mathbf{0}$ & $\mathbf{0}$ \\
A. scabra & 5 & 3 & 13 & 0 & 0 \\
J. serrei & 0 & 0 & 0 & 0 & 0 \\
M. carcinus & 10 & 1 & 4 & 1 & 0 \\
M. crenulatum & 10 & 16 & 2 & 8 & 0 \\
M. heterochirus & 15 & 27 & 12 & 18 & 10 \\
Potimirim sp. & 0 & 0 & 0 & 0 & 0 \\
X. elongata & 17 & 0 & 5 & 2 & 1 \\
total & 1676 & 274 & 785 & 1149 & 257 \\
density (ind. $\left./ \mathrm{m}^{2}\right)$ & 6.98 & 1.37 & 4.62 & 10.45 & 1.71 \\
\hline
\end{tabular}


Table 4. Results of mean comparison tests (PAS vs RS) between different species and sites from the Grand-Carbet River. $\mathrm{t}=$ Student $\mathrm{t}$-test, $\mathrm{u}=$ Mann-Whitney U-test.

\begin{tabular}{|c|c|c|c|c|c|c|c|c|c|}
\hline & \multicolumn{3}{|c|}{ A. innocous } & \multicolumn{3}{|c|}{ M. faustinum } & \multicolumn{3}{|c|}{ M. poeyi } \\
\hline & Stat & df & $\mathrm{p}$ & Stat & df & $\mathrm{p}$ & Stat & $\mathrm{df}$ & $\mathrm{p}$ \\
\hline Site 1 & $t=0.451$ & 103 & 0.653 & $\mathrm{t}=1.034$ & 675 & 0.301 & $t=-1.729$ & 922 & 0.084 \\
\hline Site 2 & $\mathrm{u}=540.5$ & & 0.497 & $\mathrm{t}=-2.407$ & 101 & 0.018 & $\mathrm{t}=-7.321$ & 238 & $<0.001$ \\
\hline Site 3 & $u=201.5$ & & 0.486 & $\mathrm{u}=$ & & 0.496 & $\mathrm{t}=-0.992$ & 226 & 0.322 \\
\hline Site 4 & $t=-6.783$ & 312 & $<0.001$ & & & & & & \\
\hline Site 5 & $t=4.878$ & 493 & $<0.001$ & & & & & & \\
\hline
\end{tabular}

Table 5. Main benefits and disadvantages of PAS and RS.

\begin{tabular}{lll}
\hline & PAS & RS \\
\hline replications within study area & numerous & few \\
sampling representativeness & high & questionable \\
investment of time, cost and effort & low & high \\
living stock estimation & difficult & easy \\
minimal perception level & microhabitat & stream reach \\
autecological study & for abundant and scarce & only for abundant \\
& species & species \\
\hline
\end{tabular}

